\title{
COVID-19 AND SUBJECTIVE WELL-BEING: PERCEIVED IMPACT, POSITIVE PSYCHOLOGICAL RESOURCES AND PROTECTIVE BEHAVIOR
}

\author{
T.G. BOKHAN ${ }^{\mathrm{a}}$, E.V. GALAZHINSKY ${ }^{\mathrm{a}}$, D.A. LEONTIEV ${ }^{\mathrm{b}}$, \\ E.I. RASSKAZOVA ${ }^{b, c}$, O.V. TEREKHINA ${ }^{a}$, A.L. ULYANICH ${ }^{a}$, \\ M.V. SHABALOVSKAYA ${ }^{a}$, S.A. BOGOMAZ ${ }^{\mathrm{a}}$, T.A. VIDYAKINA ${ }^{\mathrm{a}}$
}

\author{
${ }^{a}$ Tomsk State University, 36 Lenin Ave., Tomsk, 634050, Russian Federation \\ ${ }^{b}$ HSE University, 20 Myasnitskaya Str., Moscow, 101000, Russian Federation \\ 'Lomonosov Moscow State University, 1 Leninskie Gory, Moscow, 119991, Russian Federation
}

\begin{abstract}
While negative psychological effects of COVID-19 pandemic are actively studied, little is known about the eventual positive reactions to the pandemic including the capacity to see positive opportunities in this situation and about personality resources that may help to cope and to maintain well-being despite lifestyle restrictions. The aim of our study was to reveal positive personality resources that contribute to buffering the negative effects and its consequences on individual lives. 474 adults 18-81 years old from Siberia (Russia) participated in May 2020 in a survey about the impact of the pandemic and self-isolation and also filled out psychometric measures of well-being and psychological resources (PANAS, PWI, Value of Life Scale, MHC, MSTAT-I, LOT, GSE, Hardiness Survey, SOC, Personal Life Position inventory). One in three respondents reported worsening emotional condition through the previous two weeks and poor adherence to governmental self-isolation recommendations, and $43.6 \%$ reported increased financial difficulties. Taking into account not only the negative but also positive subjective effect of the pandemic enabled the improved accuracy in prediction of both well-being and adherence to the governmental measures. The less a person mentioned the positive side of the pandemic, the more strongly their adherence to the governmental measures depended on perceived negative effects (worries and threats). Tolerance for ambiguity, the challenge component of hardiness, harmony with life predicted perceived positive effects after adjusting for negative effects. Psychological resources could play a buffering role as regards the vulnerability to negative psychological effects of the pandemic and help to find positive opportunities.
\end{abstract}

Keywords: perceived effect of pandemic, positive psychology, well-being, personality resources, COVID-19 pandemic, adherence to governmental measures.

\section{Introduction}

The COVID-19 pandemic has been spreading worldwide since the beginning of this current year; Russia is not an exception. Although at the present moment (mid-July), the city of Moscow, which has registered about half of the national

The study was supported by the Russian Science Foundation, project № 18-18-00480 “Subjective indicators and psychological predictors of quality of life". 
infection cases for the first several months, seems to have passed the peak, in many other regions the statistics still seem to show an upward trend.

In Russia's region of Siberia, the first COVID-19 cases were registered in early March; since March 31, in most Siberian provinces the self-isolation regimen was officially introduced that has been prolonged several times and is still active. All inhabitants were strongly recommended to stay at home as much as possible, to minimize their presence in public places including public transport, to keep at a minimum "social distance" of two (in some cases three) meters from each other, and to use personal protective measures (masks, respirators, gloves, antiseptic liquids, etc.).

The developing pandemic generated many negative psychological effects associated with both the direct fear of infection, worries about the social consequences (losing a job, a worsening financial situation), broken plans, global uncertainty regarding the future, etc. Both the pandemic situation and the governmental decisions and requirements significantly restricted people's freedom of choice and planning.

Quite a number of public surveys and psychological studies related to the psychological effects of the pandemic are being conducted and published. The studies report on the variety of people's reactions to the requirements, ranging from conformist compliance to total denial. At the early stage of the pandemic (late March) studies reported growing anxiety, fears, panic, stress, magical thinking, somatization, religious coping, decreasing critical thinking, curiosity, denial and rationalization coping strategies (Enikolopov et al., 2020; Boyko et al., 2020). A number of dispositional, cognitive and situational predictors of both rational explanations of the pandemic and following the behavioral requirements have been revealed (Kubrak \& Latynov, 2020). Many studies worldwide report on mass negative psychological effects of this kind (see e.g. theoretical and empirical reviews: Nestik, 2020).

A more differentiated analysis showed that the pandemic-related anxiety is associated with negative emotions, but not with positive ones and that active and problem-oriented coping strategies are based on positive emotions and well-being rather than on the pandemic-related anxiety (Rasskazova et al., 2020). This is in line with the theory of separate regulatory systems of behavioral activation and behavioral inhibition associated with positive and negative emotions, correspondingly (Gray, 1982), and with the idea of the buffering function of positive emotions and character strengths preventing the negative effects of life adversities (Seligman, 2002). The creativity process is considered as a mechanism that operates at different levels and stages of coping process and allows the person to use vital difficulties as a possibility for personal growth (Antsiferova, 1994; Rasskazova \& Gordeeva, 2011). In the COVID-19 context, the buffering effects of self-control as regards mental health effects have been found (Li et al., 2020).

Following these considerations, we decided to focus in our study not only on evident negative emotional consequences of the pandemic, but also on positive aspects of life appraisal, on the subjective indices of quality of life and subjective well-being and on personality resources (dispositions and life strategies) which might help a person to cope with the mass of adverse conditions generated by the pandemic. The aim of our study was to reveal positive personality resources that 
might contribute to buffering the negative effects of the pandemic and its consequences on individual lives.

\section{Hypotheses}

Hypotheses of the study:

1. Perceived positive effects of the pandemic are associated with higher overall well-being and better adherence to governmental measures after adjusting for subjective negative effects.

2. The more people search for and find positive effects of the pandemic on their lives, the less their well-being and adherence to governmental measures is affected by their negative experiences during the pandemic.

3. Personality resources (tolerance for ambiguity, optimism, hardiness, self-efficacy, active life position, sense of coherence) predict perceived positive effects of the pandemic on individual life despite (after adjusting for) negative effects of the pandemic.

\section{Participants}

The study enrolled 474 respondents aged 18 to 81 years (mean age $35.92 \pm$ 14.38 years), 84 men and 381 women (9 persons did not indicate their gender), inhabitants of Siberia, specifically the Tomsk region (43.2\%), Kemerovo region (20.8\%), Krasnoyarsk region (15.2\%) and other territories of Siberia (20.8\%). Most respondents (69.6\%) had completed higher education or an academic degree, $27.5 \%$ of respondents reported incomplete higher education, $2.9 \%$ of respondents had secondary comprehensive or secondary special education. Most respondents were employed $(64.4 \%)$, of them $40.4 \%$ in state-owned industry, $12.4 \%$ private business employees and $11.6 \%$ department officers. At the time of the study, most respondents (53.7\%) were married, $46.3 \%$ were single. $55.2 \%$ of respondents had no children, $44.8 \%$ of respondents had one or two children, only $1.9 \%$ indicated that they had three or more children.

\section{Procedure}

The respondents completed online questionnaires during the period from May 1 until May 21, 2020, during the period of self-isolation, which had been officially introduced on March 31, 2020 in most areas and territories of Siberia. The study participants were invited to fill in the questionnaire via the Internet platform https://www.1ka.si/ that required on average about 30 minutes. The questionnaire was disseminated through social media as well as through the website of Tomsk State University.

\section{Measures}

Two different sets of measures were included in the study: (I) a checklist assessing different effects of the pandemic and self-isolation on the participants' lives, 
and (II) psychometric scales assessing subjective well-being and personality resources.

The checklist included 33 items describing the perceived effect of the pandemic on individual life, current changes in mood and physical condition, professional perspectives, financial situation, pandemic-related anxiety and attitude to the selfisolation regimen (including adherence to governmental recommendations). Participants appraised each item using a 5-point Likert-type scale. Four compound indices (negative and positive perceived effects of the pandemic, passive adherence to governmental measures and active protective behavior) were computed based on this checklist. We used two types of scales to differentiate perceived negative and positive effects of the pandemic on the participants' lives: unipolar and bipolar ones. The unipolar items were then integrated into the perceived negative effect scale and the bipolar items into the perceived positive effect scale.

The scale of negative perceived effect of the pandemic included 16 unipolar 5 -point items $(\alpha=.87)$ describing pandemic- and job-related worries and negative feelings that could vary from neutral (e.g., no worries) to the negative point (strong worries). In particular, there were 3 items about job-related problems ("I worry that I will likely lose my job soon", "I'm worried that I have lost my job", "I feel uncertain about keeping my work in the future" with responses ranging from 1 - "totally disagree" to 5 - "totally agree") and 13 items requesting to estimate different pandemic-related worries: "negative economic consequences", "the probability of being infected", "the probability of my relatives being infected", "the change of the routine of my life", "my plans being canceled", "losing my earnings", "problems with my physical condition and health", "problems with the physical condition and health of my relatives", "problems with my emotional state and mental health", "problems with the emotional state and mental health of my relatives", "difficulties with my children's education", "possible complications after COVID19", "incapacity of the medical system to provide assistance in case of COVID-19" with responses ranging from 1 - "don't bother at all" to 5 - "strongly worried".

The scale of positive effect of the pandemic included 7 bipolar items $(\alpha=.87)$ describing general, professional, financial, physical and emotional changes in the person's life related to the pandemic which could range from the negative pole (e.g., "worsened") through a neutral point ("no changes") to the positive pole (e.g., "improved"). There was one general item ("In what direction have the current changes associated with the COVID-19 pandemic influenced your life?", the answers ranging from 1 - "only negatively" to 5 - "only positively"), three finance- and job-related items ("I am glad that I need not do this work anymore", "I am happy that I have acquired new skills and competences, opened up new opportunities in my work" with responses ranging from 1 - "totally disagree" to 5 "totally agree"; "Your financial resources during the pandemic...", the answers ranging from 1 - "markedly decreased" to 5 - "markedly increased") and two items about current feelings and adherence to governmental measures ("The last two weeks you feel ...", with responses ranging from 1 - "very poor" to 5 - "very good"; "To stay isolated is...", with responses ranging from 1 - "very hard for me" to 5 "very easy for me"). The correlation between the scales for perceived negative and 
positive effects of the pandemic was not very high $(r=-.44, p<.01)$. While the unipolar scale of the negative effect characterized only presence or absence of negative feelings and expectations in the situation of pandemic, the bipolar scale of the positive effect included both negative and positive reactions. To further study and to predict only positive reactions to the pandemic, we adjusted in our analyses for negative effect of pandemic as a first step in hierarchical regressions.

Principal Component Analysis of 10 items describing different actions that a person could perform to minimize his or her chances of being infected revealed two components explaining $50.15 \%$ of variance. The respondents' responses ranged from 1 - "never" to 5 - "always". Five items comprised the scale of adherence to governmental measures: "I wash my hands more often", "I avoid crowded places", "I follow the regime of self-isolation and try not to leave my home", "I try to convince others to take care", "I keep the distance when in contact with others"; $\alpha=.79$ ). The other 5 items comprised the scale of active protective behavior ("I wear a mask", "I wear gloves", "I use disinfectants to treat my hands and objects", "I take medicines to improve my immunity", "I do exercises or other physical activity to improve my immunity"; $\alpha=.62$ ).

Methods assessing subjective well-being included (1) Index of Personal Wellbeing, PWI (International Wellbeing Group, 2013, translated by E. A. Uglanova) that consisted of seven items concerning evaluation of satisfaction with spheres of life: standard of living, health, achievement, relationships with relatives, personal security, relations with neighbors, confidence in the future; $\alpha=.88$. (2) The scale of positive and negative affect, PANAS (shortened version) includes twelve adjectives describing six positive emotions and six negative emotions which make the scale of positive affect $(\alpha=.85)$ and the scale of negative affect $(\alpha=.92)$ (Watson et al., 1988; Osin, 2012). (3) The Value of Life Scale by D. A. Leontiev (unpublished) is a semantic differential type self-report technique for evaluating one's life by 5 bipolar scales composed of opposite adjectives $(\alpha=.94)$. (4) The Mental Health Continuum, MHC (Keyes, 2009; Osin \& Leontiev, 2020) includes three scales: emotional hedonic well-being $(\alpha=.83)$, social eudaimonic well-being $(\alpha=.79)$, psychological eudaimonic well-being $(\alpha=.86)$. All the measures of subjective well-being were highly consistent with each other $(\alpha=.85)$ and were factor analyzed together (Principal Component Method) to compute the compound Index of Subjective Wellbeing (the only component, which explained $54.71 \%$ percent of variance; factor loadings varied in their absolute values .65-.84). Factor scores were computed based on regression coefficients.

Methods assessing personality resources included: (1) The Multiple Stimulus Types Ambiguity Tolerance Scale II, MSTAT-II (McLain, 1993; Leontiev et al., $2016)$ to assess the ability to endure uncertain and ambiguous situations $(\alpha=.87)$. (2) The Life Orientations Test of dispositional optimism, LOT (Scheier, Carver, 1985; Gordeeva et al., 2010, $\alpha=.82$ ). (3) General Self-Efficacy Scale, GSES (Schwarzer et al., 1996, $\alpha=.89$ ). (4) Personal Life Position inventory, PLP (Leontiev \& Shilmanskaya, 2019) to assess one's attitude to one's life on three dimensions, Harmony with one's Life $(\alpha=.84)$, Awareness of Life $(\alpha=.69)$, and Agency $(\alpha=.74)$. (5) The brief version of Hardiness test (Osin \& Rasskazova, 
2013) which measures the capacity to endure stressful situations and includes three scales: Commitment $(\alpha=.79)$, Control $(\alpha=.74)$, and Challenge $(\alpha=.72)$. (6). The Sense of Coherence Scale, SOC (A. Antonovsky, (brief form Osin, 2007) that characterizes the potential of healthy development and psychological stability $(\alpha=.83)$.

While all the personality resources were consistent with each other $(=.84)$, we computed the compound Index of Personality Resources based on Principal Component Analysis of the scores on optimism, self-efficacy, hardiness, sense of coherence, agency and harmony. Tolerance for ambiguity and life awareness were excluded from the analysis as they were poorly connected with the general index, and their addition to the model decreased the consistency. The single factor structure explained $53.39 \%$ of variance with factor loadings varied .56-.83. Factor scores on the Index of Personality Resources for each respondent were computed based on the regression equation.

It should be noted that indexes of subjective well-being and personal resources had strong positive correlation $(r=.76, p<.01)$, which is reasonable from a positive psychology perspective.

The data was processed in SPSS Statistics 23.0 and included descriptive statistics, correlational analysis, factor analysis, hierarchical regression analysis and moderation analysis.

Each respondent signed an informed consent form before starting to answer survey questions. The study was approved by the Ethics Committee of Interdisciplinary Research of Tomsk State University on 22.04.2020.

\section{Results}

\section{Negative and Positive Reactions to the Pandemic and Adherence to Governmental Measures}

Most respondents reported a significant impact of changes associated with the COVID-19 pandemic on their lives. With regard to the scale of negative perceived effect of the pandemic, it was found that the professional situation got worse for the majority of respondents (56.8\%). Nevertheless, a rather small percentage of them are afraid of losing their job: $12.8 \%$ of respondents worry that they will likely lose their job soon, $7.6 \%$ of them are worried that they have already lost their job, but at the same time $25.1 \%$ feel uncertain about keeping their job in the future. The comparison of dominant worries shows that our respondents are most of all concerned with the health of the people close to them: their risk of COVID-19 infection (80.3\%), problems with their physical and mental health $(70.1 \%$ and $58.3 \%$, correspondingly). One's own health is much less worrying $(42.3 \%, 42.1 \%$ and $45.3 \%$ ), even compared to unfavorable economic consequences (73.1\%), cancellation of plans (55.0\%) and risk of lost earnings (46.0\%).

According to the answers to the questions included in the scale of positive effect of the pandemic the almost half of respondents (46.1\%) reported both negative and positive effects; $39.8 \%$ reported only negative effects, and $14.1 \%$ reported only positive 
ones. Changes in health and financial situation were distributed in a similar way: negative changes prevailed over positive ones, but at least half of the respondents (53.3\% and 50.0\%, respectively) reported the absence of changes. $60.2 \%$ claim that they acquired new skills and competences and discovered new professional opportunities. More than half of the respondents (53.3\%) in the last two weeks feel ok as always, $11.6 \%$ feel better than before and very good.

Most of the respondents used the following protective measures and adherence to governmental measures: hand washing (86.7\%), avoiding crowded places (80.4\%), self-isolation (73.5\%), keeping "social distance" (71.6\%). Less popular is using sanitizers $(55.0 \%)$, physical exercises (4.1\%) and wearing masks (39.5\%); the rarest were taking medicines for improving immunity (16.9\%) and wearing protective gloves (14.1\%). Many (41.3\%) took care of those in groups considered to be at risk.

The age-related characteristics of psychological and behavioral responses to the pandemic were identified using a correlation analysis (Spearman's criterion) of age and the responses of respondents to the checklist questions. It is shown that with age respondents less often felt that the pandemic has a significant impact on their lives $(r=-.13, p<0.01)$, and evaluated this effect less negatively $(r=-.10$, $p<0.05)$. Younger participants reported less improvement of professional opportunities in the situation of a pandemic $(r=.22, p<.01)$ and less new skills and competencies $(r=.16, p<.01)$, more worries about possible job loss $(r=-.15, p<.01)$, less confidence in the future $(r=-.10, p<.05)$, poorer financial situation $(r=.16$, $p<.01)$. However, younger participants were happier that they did not have to do their ordinary work in this situation $(r=-.19, p<.01)$. For protective actions against the coronavirus infection, older respondents used gloves $(r=.12, p<.01)$ and took medications to improve immunity $(r=.10, p<.01)$. The concerns about possible consequences of the coronavirus pandemic among older respondents were associated with concerns about the economic consequences $(r=.13, p<.01)$ and difficulties in educating children $(r=.17, p<.01)$. At the same time, young respondents were more worried about the possibility of infecting people close to them $(r=-.14$, $p<.01)$, the physical $(r=-.14, p<.01)$ and emotional health of those close to them $(r=-.21, p<.01)$, the change of routine in their own life $(r=-.12, p<.01)$, their emotional state and mental health $(r=-.25, p<.01)$, loss of earnings $(r=-.13$, $p<.01$ ), as well as the inability of the medical system to provide assistance in case of a COVID-19 diagnosis $(r=-.09, p<.05)$. This was generally in line with the data obtained in Turkey (Yıldırım et al., 2021). In general, elder participants reported a slightly more positive $(r=.17, p<.01)$ and less negative $(r=-.13$, $p<.01)$ effect of the pandemic on their lives, and slightly higher active protective behavior $(r=.11, p<.05)$, but age was unrelated to passive adherence to governmental measures $(r=.04, p<.05)$.

We revealed only a few minor differences in reactions to the pandemic between males and females. Compared to males, females reported higher adherence to governmental measures (e.g., staying at home if possible; $t=-2.23, p<.05$, Hedges' $\mathrm{g}=.30$ ), a more frequent use of sanitizers $(t=-2.43, p<.05$, Hedges' $\mathrm{g}=.29)$ and maintaining social distance $(t=-2.21, p<.05$, Hedges' $g=.29)$. They were more worried than males by the probability of being infected by coronavirus $(t=-2.33, p<.05$, 
Hedges' $\mathrm{g}=.30)$, by problems with their emotional or mental health $(t=-2.34$, $p<.05$, Hedges' $\mathrm{g}=.29$ ) and by possible treatment complications in the case of infection $(t=-2.05, p<.05$, Hedges' $g=.26)$. No gender differences were revealed for either perceived negative and perceived positive effects of the pandemic. However, females on average adhered more to governmental measures than did males $(t=-2.44, p<.05$, Hedges' $g=.29)$ and more actively engaged in protective behavior $(t=-2.68, p<.01$, Hedges' $\mathrm{g}=.32)$. This also had a good correspondence with prior Turkish data (Yıldırım et al., 2021).

\section{Perceived Positive Effects of the Pandemic, Well-Being and Adherence to Governmental Measures}

Correlations (Pearson's criterion) between positive and negative perceived effects of the pandemic, positive and negative affect, and the compound index of psychological well-being were as predicted: all positive measures (Positive effect of pandemic on individual life, Well-being index, Positive emotions) significantly positively correlated ( $r$ varied $.47-.74 ; p<.01)$ with one another and significantly negatively ( $r$ varied $-.27--.74 ; p<.01)$ with negative measures (Negative effect of pandemic on individual life, Negative emotions). Less trivial associations were found for two forms of protective behaviors: adherence to governmental measures and active self-protection. Both significantly positively correlated with the perceived negative impact of COVID-19 (accordingly, $r=.25$ and $r=.18 ; p<.01$ ) and with each other $(r=.48 ; p<.01)$ and lacked significant correlations with positive and negative affect and with positive impact of the pandemic; only active protective behavior was significantly associated with the compound well-being index (specifically with eudaimonic psychological well-being $(r=.16 ; p<.01)$, eudaimonic social well-being $(r=.18 ; p<.01)$ and the value of life $(r=.15 ; p<.01))$.

To reveal the relationship between the specific positive effect of the pandemic, subjective well-being and protective behavior, a series of moderation analyses using hierarchical regression was performed. Dependent variables were the index of well-being, positive and negative emotions, adherence to governmental measures, and active protective behavior. At the first step of the analysis, we adjusted for negative effects of the pandemic (centered). At the second step, the positive effect of pandemic was added as an independent variable (centered). Improvement of the model (in terms of $\mathrm{R}^{2}$ ) at the second step of the regression demonstrated that taking into consideration the specific positive reaction to the pandemic could be important in prediction of well-being and behavior regardless of (controlling for) negative reaction to the pandemic. At the third step, we added as a moderator the interaction term for positive and negative effects of the pandemic. Improvement of the model (in terms of $\mathrm{R}^{2}$ ) at the third step of the regression characterized the situation when the relationship between behavior, well-being and negative effect of pandemic was different in people with high and low positive effect of pandemic.

After adjusting for the perceived negative effects of the pandemic, its perceived positive effects still predicted the well-being index, positive and negative emotions as well as better adherence to official recommendations (Table 1). 
Table 1

Perceived Positive Effects of the Pandemic, Well-Being and Adherence to Governmental Measures: Results of Hierarchical Regression Analysis

\begin{tabular}{|l|c|c|c|c|}
\hline \multirow{2}{*}{ Dependent variables } & \multicolumn{2}{|c|}{$\begin{array}{c}\text { Step 1 IV: Negative effect of the } \\
\text { pandemic on the individual life }\end{array}$} & \multicolumn{2}{c|}{$\begin{array}{c}\text { Step 2 IV: Positive effect of the } \\
\text { pandemic on the individual life }\end{array}$} \\
\cline { 2 - 5 } & $\beta$ & $\mathrm{R}^{2}$ & $\beta$ & $\mathrm{R}^{2}$ \\
\hline Well-being index & $-.33^{* *}$ & $11.0 \%^{* *}$ & $.40^{* *}$ & $13.1 \%^{* *}$ \\
\hline Negative emotions & $.48^{* *}$ & $22.5 \%^{* *}$ & $-.34^{* *}$ & $9.5 \%^{* *}$ \\
\hline Positive emotions & $-.27^{* *}$ & $7.4 \%^{* *}$ & $.48^{* *}$ & $18.5 \%^{* *}$ \\
\hline $\begin{array}{l}\text { Adherence to govern- } \\
\text { mental measures }\end{array}$ & $.25^{* *}$ & $6.3 \%^{* *}$ & $.24^{* *}$ & $4.6 \%^{* *}$ \\
\hline $\begin{array}{l}\text { Active protective } \\
\text { behavior }\end{array}$ & $.18^{* *}$ & $3.3 \%^{* *}$ & $.12^{*}$ & $1.1 \%^{*}$ \\
\hline
\end{tabular}

${ }^{*} p<0.05,{ }^{* *} p<0.01$. IV - Independent Variable.

No moderation effects of the interaction between positive and negative effects of the pandemic on subjective well-being were revealed.

However, we found a moderation effect between positive and negative perceived effects of the pandemic on the adherence to governmental measures $(\beta=-.13$, $\left.p<.01, \mathrm{R}^{2}=1.7 \%\right)$. According to simple regressions, in respondents who reported lower than average positive effects of the pandemic on their lives, adherence to governmental measures was more strongly related to perceived negative effects of the pandemic such as anxiety, job loss, etc. $\left(\beta=.44, p<.01, \mathrm{R}^{2}=18.9 \%\right)$ than in respondents who reported higher than average positive effects of the pandemic $\left(\beta=.17, p<.17, \mathrm{R}^{2}=2.8 \%\right)$. In other words, the less a person mentioned the positive side of the pandemic in their life, the more strongly their adherence to governmental measures depended on perceived negative effects of the pandemic (worries and threats).

\section{Personality Resources and Perceived Positive Effects of the Pandemic on Individual Life: Results of Hierarchical Regression Analysis}

As we see from Table 2, the perceived positive impact of COVID-19 was significantly positively correlated and perceived negative impact was significantly negatively correlated with both the compound index of personality resources and all the specific relevant variables. Again, protective behaviors revealed quite a different pattern. Passive self-isolation behavior in line with governmental measures lacked significant associations with any variables related to personality resources. Unlike the latter, active protective behavior was moderately significantly positively associated with the compound Personality Resources Index and with some of the related variables, specifically with dispositional optimism and hardiness/commitment.

In line with Hypothesis 3, we completed a series of hierarchical regression analyses to reveal the relationship between personality resources and reaction to 
Table 2

Correlations of Perceived Positive and Negative Effects of the Pandemic On individual life, adherence to governmental measures and personality resources

\begin{tabular}{|l|c|c|c|c|}
\hline & $\begin{array}{c}\text { Positive effect of } \\
\text { the pandemic on } \\
\text { individual life }\end{array}$ & $\begin{array}{c}\text { Negative effect } \\
\text { of the pandemic } \\
\text { on individual life }\end{array}$ & $\begin{array}{c}\text { Adherence to } \\
\text { governmental } \\
\text { measures }\end{array}$ & $\begin{array}{c}\text { Active pro- } \\
\text { tective } \\
\text { behavior }\end{array}$ \\
\hline $\begin{array}{l}\text { Index of Personality } \\
\text { Resources }\end{array}$ & $.36^{* *}$ & $-.29^{* *}$ & .05 & $.12^{*}$ \\
\hline Tolerance for Ambiguity & $.24^{* *}$ & $-.19^{* *}$ & .02 & .05 \\
\hline Dispositional Optimism & $.29^{* *}$ & $-.12^{* *}$ & .08 & $.17^{* *}$ \\
\hline Self-Efficacy & $.19^{* *}$ & $-.16^{* *}$ & .07 & .07 \\
\hline Hardiness - Commitment & $.33^{* *}$ & $-.32^{* *}$ & .03 & $.11^{*}$ \\
\hline Hardiness - Control & $.33^{* *}$ & $-.31^{* *}$ & .04 & .09 \\
\hline Hardiness - Challenge & $.37^{* *}$ & $-.32^{* *}$ & .06 & .04 \\
\hline Life Position - Agency & $.20^{* *}$ & $-.16^{* *}$ & .02 & -.02 \\
\hline Life Position - Awareness & .05 & -.03 & .05 & -.04 \\
\hline Life Position - Harmony & $.36^{* *}$ & $-.29^{* *}$ & .01 & .06 \\
\hline Sense of Coherence & $.24^{* *}$ & $-.22^{* *}$ & .07 & .07 \\
\hline
\end{tabular}

${ }^{*} p<0.05,{ }^{* *} p<0.01$.

the pandemic. The dependent variable was the perceived positive effect of the pandemic. As earlier, at the first step of the analysis we adjusted for the negative effect of the pandemic in order to "clean away" negative reactions from the bipolar scale of the positive effect. In other words, we predicted a specific positive reaction to the pandemic that was independent of the negative reaction. At the second step, we added to the model the index of personality resources to reveal whether people with higher resources tended to react more positively in the pandemic situation. As Table 3 demonstrates, the second step improved the model, accounting for an additional $5.7 \%$ of variance, in accordance with Hypothesis 3.

Then we tried to find out which resources could be specifically helpful for more positive reactions to the pandemic. We repeated the same analysis adding each personality resource variable separately. As Table 3 shows, for all but one personal resources (life awareness) we found small effects that reached significance $(p<.01)$, indicating that different resources could be a little bit helpful; of these, probably the highest was the contribution of optimism, hardiness and sense of harmony.

Finally, we forced personal resources to "compete" with each other in a stepwise regression analysis, in an attempt to figure out some optimal number of predictors of a positive reaction to the pandemic. Sense of harmony, hardiness challenge and tolerance to ambiguity were the predictors in this stepwise model, adding $7.3 \%$ of variance in explaining specific positive reaction to the pandemic (regardless of its negative effect). 
Table 3

Perceived Positive Effects of the Pandemic on Individual Life: The Role of Personality Resources After Adjusting for Perceived Negative Effects of the Pandemic

\begin{tabular}{|c|c|c|c|}
\hline \multirow{2}{*}{$\begin{array}{l}\text { Steps of } \\
\text { hierarchical } \\
\text { regression } \\
\text { analysis }\end{array}$} & \multirow{2}{*}{ Independent variables } & \multicolumn{2}{|c|}{$\begin{array}{l}\text { DV: Positive effect of the } \\
\text { pandemic on individual life }\end{array}$} \\
\hline & & $\beta$ & $\mathrm{R}^{2}$ \\
\hline \multicolumn{4}{|c|}{ Basic model for index of personality resources } \\
\hline Step 1 & Negative effect of the pandemic on individual life & $-.44^{* *}$ & $19.5 \% * *$ \\
\hline Step 2 & Index of Personality Resources & $.25^{* *}$ & $5.7 \% * *$ \\
\hline \multicolumn{4}{|c|}{ Separate models for different personality resources } \\
\hline Step 2 & Tolerance for Ambiguity & $.16^{* *}$ & $2.5 \% * *$ \\
\hline Step 2 & Dispositional Optimism & $.18^{* *}$ & $3.3 \% * *$ \\
\hline Step 2 & Self-Efficacy & $.12^{* *}$ & $1.3 \% * *$ \\
\hline Step 2 & Hardiness - Commitment & $.21^{* *}$ & $3.8 \% * *$ \\
\hline Step 2 & Hardiness - Control & $.21^{* *}$ & $3.9 \%$ ** \\
\hline Step 2 & Hardiness - Challenge & $.24^{* *}$ & $5.3 \%^{* *}$ \\
\hline Step 2 & Life Position - Agency & $.13^{* *}$ & $1.7 \% * *$ \\
\hline Step 2 & Life Position - Awareness & .04 & $0.2 \%$ \\
\hline Step 2 & Life Position - Harmony & $.25^{* *}$ & $5.8 \% * *$ \\
\hline Step 2 & Sense of Coherence & $.14^{* *}$ & $1.9 \% * *$ \\
\hline \multicolumn{4}{|c|}{ General model (stepwise regression) } \\
\hline \multirow{2}{*}{ Step 1} & Negative effect of the pandemic on individual life & $-.44^{* *}$ & $19.5 \% * *$ \\
\hline & Life Position - Harmony & $.15^{* *}$ & $7.3 \% * *$ \\
\hline \multirow{2}{*}{ Step 2} & Hardiness - Challenge & $.12^{*}$ & \\
\hline & Tolerance to Ambiguity & $.09^{*}$ & \\
\hline
\end{tabular}

${ }^{*} p<0.05,{ }^{* *} p<0.01$. DV - Dendependent Variable.

\section{Discussion}

The results of our study presented above can be divided into two parts.

The first, descriptive in nature, reveals the perceived impact of the COVID-19 pandemic in the Siberian region of Russia and the typical forms of protective behavior, with the reservation that our data is in no way representative for the region. In particular, women and educated respondents were overrepresented, while men and respondents with lower education were underrepresented. Nevertheless, our data in this respect was in a rather good correspondence with similar data collected in other regions of the world (see below).

Having included not only the measures of the negative effects of the pandemic but also the positive effects and using symmetrical scales, we found that most respondents reported that the pandemic affected their lives, but mostly there were mixed effects including both negative and positive sides. One in three respondents thought that their emotional condition had worsened over the last two weeks and $43.6 \%$ reported that that their financial opportunities worsened. About one half of the respondents reported on both positive and negative effects or did not notice 
notable changes. One person in three did not adhere to governmental self-isolation recommendations.

Counter to our expectations, younger respondents were more anxious about both the epidemiological and economic effects of the pandemic. This, however, is in line with the published data from other regions of the world, in India (Varshney et al., 2020), Pakistan (Balkhi et al., 2020) and China (Huang \& Zhao, 2020). Negative emotions and worries were stronger in younger respondents, likely because of the probable greater impact of social media on them.

Our respondents were quite empathic: they worried about the health of the people close to them more than about their own health. Worries about the economic effects of the pandemic took an intermediate position. As we have seen, the current pandemic situation is challenging for the population, but still not traumatic or critical for most of them, even ambivalent for many.

The second part of our analysis referred to the associations and interactions between the assessed variables, particularly between the perceived impact of the COVID-19 pandemic, subjective measures of quality of life and subjective wellbeing and personality resources.

In particular, subjective well-being, positive affect and positive perceived impact of the pandemic turned out to play an independent role in responding to this adverse condition. After adjusting for the perceived negative effect of the pandemic, the more people mentioned positive effects of the pandemic on their lives, the higher their general wellbeing and the better the adherence to governmental measures they reported. Moreover, the relationship between the negative effect of the pandemic and self-isolation was moderated by the positive effect of the pandemic. The less a person mentioned the positive side of the pandemic, the more strongly their adherence to governmental measures depended on perceived negative effects of the pandemic (worries and threats). The more positively disposed a person was, the more active was protective behavior and the less it was determined by perceived external obstacles. Positive appraisal of the pandemic situation (not in the sense of evaluating it as positive but in the sense of finding positive and manageable aspects of the situation) seemed to fulfill a buffering function, decreasing the person's vulnerability in the face of an uncommon, yet shared, threat.

Analogously, the buffering function was fulfilled by positive personality resources of a dispositional nature (specifically, tolerance for ambiguity, the challenge component of hardiness, harmony with one's life). These predicted the perceived positive effects of the pandemic on individual life despite (after adjusting for) the negative effects of the pandemic.

Our results thus not only describe the picture of the psychological effects of the COVID-19 pandemic in the Siberian region of Russia, but also highlight some factors which may play a buffering role as regards the vulnerability to negative psychological effects of the pandemic.

\section{Conclusion}

Most respondents of our survey in the Siberian region of Russia seemed to perceive the COVID-19 pandemic as rather ambivalent including both negative and 
positive aspects. This ambivalent attitude to the pandemic was more prominent in elderly respondents. In accordance with Hypothesis 2, taking into account not only negative but also positive perceived effects of the pandemic allowed us to improve the prediction of both well-being and the adherence to governmental measures. The less a person mentioned the positive side of the pandemic in their life, the more strongly their adherence to governmental measures depended on the perceived negative effects of the pandemic (worries and threats).

Personality resources (specifically, tolerance for ambiguity, the challenge component of hardiness, sense of harmony with one's life) predicted the perceived positive effects of the pandemic on individual life despite (after adjusting for) its negative effects.

\section{Acknowledgements}

The authors are grateful to Dr. Martin F. Lynch for helping to improve the text stylistically.

\section{References}

Antsiferova, L. I. (1994). Lichnost' v trudnykh zhiznennykh usloviyakh: pereosmysleniye, preobrazovaniye situatsii i psikhologicheskaya zashchita [A person in difficult living conditions: reinterpretation, transformation of situations and psychological protection]. Psikhologicheskii Zhurnal, 15(1), 3-18.

Balkhi, F., Nasir, A., Zehra, A., \& Riaz, R. (2020). Psychological and behavioral response to the coronavirus (COVID-19) pandemic. Cureus, 12(5), Article e7923. https://doi.org/10.7759/cureus.7923

Boyko, O. M., Medvedeva, T. I., Enikolopov, S. N., Vorontsova, O. Yu., \& Kazmina, O. Yu. (2020). The psychological state of people during the COVID-19 pandemic and the target of psychological work. Psikhologicheskie Issledovaniya, 13(70), 1. http://psystudy.ru (in Russian)

Enikolopov, S. N., Boyko, O. M., Medvedeva, T. I., Vorontsova, O. U., \& Kazmina, O. U. (2020). Dynamics of psychological reactions at the start of the pandemic of COVID-19. PsychologicalEducational Studies, 12(2), 108-126. https://doi.org/10.17759/psyedu.2020120207 (in Russian)

Gordeeva, T. O., Sychev, O. A., \& Osin, E. N. (2010). Razrabotka russkoyazy`chnoj versii testa dispozicionnogo optimizma [Development of a Russian-language version of the dispositional optimism Test]. Psikhologicheskaya Diagnostika, 2, 36-64.

Gray, J. A. (1982). On mapping anxiety. Behavioral and Brain Sciences, 5(3), 506-534. https://doi.org/10.1017/S0140525X00013297

Huang, Y., \& Zhao, N. (2020). Generalized anxiety disorder, depressive symptoms and sleep quality during COVID-19 outbreak in China: a web-based cross-sectional survey. Psychiatry Research, 288, Article 112954. https://doi.org/10.1016/j.psychres.2020.112954

Kubrak, T. A., \& Latynov, V. V. (2020). Opportunities and limitations of information-psychological influence in the situation of the coronavirus pandemic. Institut Psikhologii Rossiiskoi Akademii Nauk. Sotsial'naya i Ekonomicheskaya Psikhologiya [Institute of Psychology of the Russian Academy of Sciences. Social and Economic Psychology], 5(2), 84-114. https://doi.org/10.38098/ ipran.sep.2020.18.2.003 (in Russian)

Leontiev, D. A., Osin, E. N., \& Lukovitskaya, E. G. (2016). Diagnostika tolerantnosti k neopredelennosti. Shkaly D. Makleina [Diagnostics of tolerance to ambiguity: D. McLane scales]. Moscow: Smysl. 
Leontiev, D. A., \& Shilmanskaya, A. E. (2019). Personal life position: Making theoretical notions operational. Voprosy Psikhologii, 1, 90-100. (in Russian)

Li, J. B., Yang, A., Dou, K. \& Cheung, R. Y. (2020). Self-control moderates the association between perceived severity of the coronavirus disease 2019 (COVID-19) and mental health problems among the Chinese public. PsyArXiv. https://doi.org/10.31234/osf.io/2xadq

Nestik, T. A. (2020). The impact of the COVID-19 pandemic on society: socio-psychological analysis. Institut Psikhologii Rossiiskoi Akademii Nauk. Sotsial'naya i Ekonomicheskaya Psikhologiya [Institute of Psychology of the Russian Academy of Sciences. Social and Economic Psychology], 5(2), 47-83. https://doi.org/10.38098/ipran.sep.2020.18.2.002 (in Russian)

Osin, E. N. (2007). Chuvstvo svyaznosti kak pokazatel' psikhologicheskogo zdorov'ya i ego diagnostika [Sense of coherence as an indicator of mental health and its diagnosis]. Psikhologicheskaya Diagnostika, 3, 22-40.

Osin, E. N. (2012). Measuring positive and negative affect: Development of a Russian language analogue of PANAS]. Psychology. Journal of the Higher School of Economics, 9(4), 91-110. (in Russian)

Osin, E. N., \& Leontiev, D. A. (2020). Brief Russian-language instruments to measure subjective wellbeing: psychometric properties and comparative analysis. Monitoring of Public Opinion: Economic and Social Changes, 1, 117-142. https://doi.org/10.14515/monitoring.2020.1.06 (in Russian)

Osin, E. N., \& Rasskazova, E. I. (2013). A short version of the Hardiness Test: Psychometric properties and organizational application. Moscow University Psychology Bulletin, 2, 147-165. (in Russian)

Rasskazova, E. I., \& Gordeeva, T. O. (2011). Coping strategies in the psychology of stress: approaches, methods, perspectives. Psikhologicheskie Issledovaniya, 3(17), 4. http://psystudy.ru/ index.php/eng/2011n3-17e/505-rasskazova-gordeeva17e.html (in Russian)

Rasskazova, E. I., Leontiev, D. A., \& Lebedeva, A. A. (2020). Pandemic as a challenge to subjective wellbeing: anxiety and coping. Konsul'tationaya Psikhologiya i Psikhoterapiya [Counseling Psychology and Psychotherapy], 28(2), 90-108. https://doi.org/10.17759/cpp.2020280205 (in Russian)

Schwarzer, R., Erusalem, M., \& Romek, V. (1996). Russkaya versiya shkaly obshchei samoeffektivnosti R. Shvartsera i M. Erusalema [Russian version of the General Self-Efficacy scale by R. Schwarzer and M. Erusalem]. Inostrannaya Psikhologiya, 7, 71-77.

Seligman, M. E. P. (2002). Authentic happiness: Using the new positive psychology to realize your potential for lasting fulfillment. New York, NY: Free Press.

Varshney, M., Parel, J. T., Raizada, N., \& Sarin, S. K. (2020). Initial psychological impact of COVID19 and its correlates in Indian Community: An online (FEEL-COVID) survey. PLoS ONE, 15(5), Article 0233874. https://doi.org/10.1371/journal.pone.0233874

Yıldırım, M., Geçer, E., \& Akgül, Ö. (2021). The impacts of vulnerability, perceived risk, and fear on preventive behaviours against COVID-19. Psychology, Health $\mathcal{E}$ Medicine, 26(1), 35-43. https://doi.org/10.1080/13548506.2020.1776891

Tatiana G. Bokhan - Head of the Department of Psychotherapy and Psychological Counseling, Tomsk State University, DSc in Psychology, Professor.

Research Area: psychology of stress, coping strategies, quality of life.

E-mail: btg960@mail.ru

Eduard V. Galazhinsky - Rector, Tomsk State University, DSc in Psychology, Professor, Academician of RAE.

Research Area: psychology of self-realization and self-development, psychology of leadership and management.

E-mail: gala@mail.tsu.ru 
Dmitry A. Leontiev - Head of the International Laboratory of Positive Psychology of Personality and Motivation, HSE University, DSc in Psychology, Professor.

Research Area: psychology of personality, psychology of motivation, well-being, quality of life.

E-mail:dmleont@gmail.com

Elena I. Rasskazova - Leading Research Fellow, International Laboratory of Positive Psychology of Personality and Motivation, HSE University; Associate Professor, Clinical Psychology Department, Lomonosov Moscow State University, PhD in Psychology.

Research Area: positive psychology, psychology of self-regulation, patho-psychology, health psychology, statistical methods in psychology.

E-mail: e.i.rasskazova@gmail.com

Olga V. Terekhina - Associate Professor, Department of Psychotherapy and Psychological Counseling, Tomsk State University, PhD in Psychology.

Research Area: health psychology, clinical psychology, quality of life, psychological well-being, developmental psychology.

E-mail: doterekhina@mail.ru

Anna L. Ulyanich - Associate Professor, Department of Psychotherapy and Psychological Counseling, Tomsk State University, PhD in Psychology.

Research Area: health psychology, developmental psychology, quality of life.

E-mail: FiALe@yandex.ru

Marina V. Shabalovskaya - Associate Professor, Department of Psychotherapy and Psychological Counseling, Tomsk State University, PhD in Psychology.

Research Area: quality of life, psychology of identity, psychology of value-semantic sphere, psychology of self-regulation, developmental psychology.

E-mail: m_sha79@mail.ru

Sergei A. Bogomaz - Professor, Department of Organizational Psychology, Tomsk State University, DSc in Psychology, Professor.

Research Area: psychology of personality, developmental psychology, cognitive psychology.

E-mail: bogomazsa@mail.ru

Tamara A. Vidyakina - PhD Student, Department of Psychotherapy and Psychological Counseling, Tomsk State University.

Research Area: mental states, psychological aspects and personal determinants of quality of life.

E-mail: otchet.toma@gmail.com 


\title{
COVID-19 и субъективное благополучие: воспринимаемое воздействие, позитивные психологические ресурсы и защитное поведение
}

\section{Т.Г. Бохан ${ }^{\mathrm{a}}$, Э.В. Галажинскийа ${ }^{\mathrm{a}}$ Д.А. Леонтьев ${ }^{\mathrm{b}}$, Е.И. Рассказова ${ }^{\mathrm{b}, \mathrm{c}}$, О.В. Терехина ${ }^{\mathrm{a}}$,} А.Л. Ульянич ${ }^{a}$, М.В. Шабаловская ${ }^{a}$, С.А. Богомаз ${ }^{a}$, Т.А. Видякина ${ }^{a}$

\author{
${ }^{a}$ Национальный исследовательский Томский государственный университет, 634050, Россия, \\ Томск, пр. Ленина, 36 \\ ${ }^{b}$ Национальный исследовательский университет «Высшая школа экономики», 101000, Россия, \\ Москва, ул. Мясницкая, д. 20 \\ 'Московский государственный университет имени М.В. Ломоносова, 119991, Россия, Москва, \\ Ленинские горь, 1
}

\section{Резюме}

Хотя негативные психологические последствия пандемии COVID-19 активно изучаются, мало что известно о возможных позитивных реакциях на пандемию, в том числе о способности видеть позитивные возможности в этой ситуации и о личностных ресурсах, которые могут помочь справиться и сохранить благополучие, несмотря на ограничения в образе жизни. Цель нашего исследования состояла в том, чтобы выявить позитивные личностные ресурсы, которые способствуют буферизации негативных эффектов и их последствий для жизни отдельных людей. 474 взрослых человека в возрасте 18-81 года, проживающих в Сибири (Россия), приняли участие в мае 2020 г. в опросе о влиянии пандемии и самоизоляции, а также заполнили ряд психометрических показателей благополучия и психологических ресурсов (PANAS, PWI, шкала ценности жизни, MHC, MSTAT-I, LOT, GSE, опросник жизнестойкости, SOC, инвентаризация личной жизненной позиции). Каждый третий респондент сообщил об ухудшении эмоционального состояния в течение последних двух недель, плохом соблюдении рекомендаций правительства по самоизоляции, и 43.6\% сообщили о возросших финансовых трудностях. Учет не только негативного, но и позитивного субъективного эффекта пандемии позволил повысить точность прогнозирования как благополучия, так и соблюдения государственных мер. Чем меньше человек упоминал о положительной стороне пандемии, тем сильнее его приверженность правительственным мерам зависела от воспринимаемых негативных последствий (тревог и угроз). Толерантность к неопределенности, принятие риска как компонент жизнестойкости, гармония со своей жизнью предсказывали воспринимаемые положительные эффекты пандемии, после корректировки негативных последствий. Психологические ресурсы могут играть буферную роль в отношении уязвимости к негативным психологическим последствиям пандемии и помогать находить позитивные возможности.

Ключевые слова: воспринимаемый эффект пандемии, позитивная психология, благополучие, личностные ресурсы, пандемия COVID-19, приверженность государственным мерам.

Бохан Татьяна Геннадьевна - заведующая кафедрой психотерапии и психологического консультирования, Национальный исследовательский Томский государственный университет, доктор психологических наук, профессор.

Сфера научных интересов: психология стресса, копинг-поведение, качество жизни.

Контакты: btg960@mail.ru 
Галажинский Эдуард Владимирович - ректор, Национальный исследовательский Томский государственный университет, доктор психологических наук, профессор, академик РАО.

Сфера научных интересов: психология самореализации и саморазвития личности, психология лидерства и управления.

Контакты: gala@mail.tsu.ru

Леонтьев Дмитрий Алексеевич - заведующий лабораторией, Международная лаборатория позитивной психологии личности и мотивации, Национальный исследовательский университет «Высшая школа экономики», доктор психологических наук, профессор.

Сфера научных интересов: психология личности, психология мотивации, качество жизни, субъективное благополучие.

Контакты: dmleont@gmail.com

Елена Игоревна Рассказова - ведущий научный сотрудник, Международная лаборатория позитивной психологии личности и мотивации, Национальный исследовательский университет «Высшая школа экономики»; доцент, кафедра клинической психологии, Московский государственный университет имени М.В. Ломоносова, кандидат психологических наук.

Сфера научных интересов: позитивная психология, психология саморегуляции, патопсихология, психология здоровья, статистические методы в психологии.

Контакты: e.i.rasskazova@gmail.com

Терехина Ольга Владимировна - доцент, кафедра психотерапии и психологического консультирования, Национальный исследовательский Томский государственный университет, кандидат психологических наук.

Сфера научных интересов: психология здоровья, клиническая психология, качество жизни, психологическое благополучие, психология развития.

Контакты: doterekhina@mail.ru

Ульянич Анна Леонидовна - доцент, кафедра психотерапии и психологического консультирования, Национальный исследовательский Томский государственный университет, кандидат психологических наук.

Сфера научных интересов: психология здоровья, психология развития, качество жизни.

Контакты: FiALe@yandex.ru

Шабаловская Марина Владимировна - доцент, кафедра психотерапии и психологического консультирования, Национальный исследовательский Томский государственный университет, кандидат психологических наук.

Сфера научных интересов: качество жизни, психология идентичности, психология ценностно-смысловой сферы, психология саморегуляции, психология развития.

Контакты: m_sha79@mail.ru

Богомаз Сергей Александрович - профессор, кафедра организационной психологии, Национальный исследовательский Томский государственный университет, доктор психологических наук, профессор.

Сфера научных интересов: психология личности, возрастная психология, когнитивная психология.

Контакты: bogomazsa@mail.ru

Видякина Тамара Андреевна - аспирант, кафедра психотерапии и психологического консультирования, Национальный исследовательский Томский государственный университет.

Сфера научных интересов: психическое здоровье, психологические аспекты и личностные детерминанты качества жизни.

E-mail: otchet.toma@gmail.com 